\title{
SPRAWY LITURGICZNE W XVI W. W DIECEZJI KRAKOWSKIEJ
}

\author{
PRÓBKA Z OBSZARU KILKUNASTU PARAFII.
}

Każdy szczegół z przeszłości jakiejś paralii staje się zrozumialszy, jeśli poda się, jak ten szczegół wyglądał w parafiach sąsiednich. Zaj. mując się dziejami parafii Niegowić, w diec. krakowskiej, pow. Bochnia, starałem się każdy szczegól, o ile to było możliwe, zestawiać ze stanem w parafiach sąsiednich. W ten sposób zebralem materiał do pasa między Wieliczką a Bochnią na poludnie wzdłuz Raby i jej dopływu Stradomki. Stąd weszły do opracowania stykające się z sobą części dawnego dekanatu (wiek XVIII) wielickiego, dobczyckiego i lipnickiego. Dla wielu szczegółów brałem pod uwage parafie, sąsiadujące bezpośrednio, dla niektórych włączałem Bochnię i Wieliczkę, jako najbliższe większe miasta, dla paru szczegółów sięgnąłem aż po Łętownię i Nowy Targ. Wykorzystane w ten sposób Acta Visitationis z $1596 \mathrm{r}$. pozwoliły dać obraz pewnych spraw liturgicznych, bo ta wizytacja zajmowała się nimi tak, jak już żadna następna ${ }^{1}$ ). Stosunki liturgiczne na tym pasie są niejednakowe, mogą więc mniej lub więcej reprezentować stan w calej diecezji. Dla pewności potrzebne byłyby analogiczne opracowania dla różnych okolic, biorąc pod uwagę ich odrębności np. G. Sląsk, o ile wchodził do diecezji krakowskiej, okolice górskie, choć te będą bardzo różne, np. Sądeczyzna ma od dawna (XIV w.) gęstą sieć parafialną, i okolice o rzadkiej sieci parafialnej w XIV, a wiec na wschodzie diecezji.

\section{KSIECGI LITURGICZNE.}

Msza 1 y. Na ogól wszędzie zastawał wizytator z 1596 r. Mszal rzymski reformowany. Mszal rzymski sprzed reformy ma Lapanów ²); Mszal krakowski ma Tarnawa ${ }^{3}$ ) i Łososina ${ }^{4}$ ). Łososina ma też Mszal moguncki ${ }^{5}$ ). Który Mszał krakowski ma odnośna párafia, nic podaje

1) Acta Visitationis w Arch. Kapitulnym Nr 7. Znacze skrótem: 1. V. 1596. Tak samo i inne wizytacje przez podanie rokı.

2) A. V. $1596, \mathrm{k} 65$.

3) l. e. $\mathrm{k} 67$.

4) 1. c. $\mathrm{k} \tau 2$.

ז) l. c. $\mathrm{k} 72$. 
wizytator. Pierwszy Mszał krakowski ukazał się drukiem w 1484 r staraniem ks. Bkpa krakowskiego Jana Rzeszowskiego. Drukowany był w Moguncji, tam też ukażał się Mszał krakowski w r. 1487 i 1492.

Pierwszy Mszał krakowski drukowany w Krakowie ukazał się w 1509 r., potem w 1516 i 1556, ale w międzyczasie był drukowany Mszal krakowski w Strasburgu 1510, i w Wenecji 1532 r. Czy wizytator słowem „moguncki“ określa mszał diec. mogunckiej czy też mszał krak. drukowany w Moguncji, nie da się rozstrzygnaćc.

W tym samym mniejwięcej czasie zastawali wizytatorzy na terenie archidiakonatu pomorskiego daleko większą różnorodność mszalów, będących w użyciu, choćby się nawet brało pod uwagę, że tam chodzi o znacznie większy teren, aniżeli tu omawiany. Zastali tam przeważnie Mszały rzymskie (20) ale nadto krakowskie (12), gnieźnieńskie bardzo czesto, chełmińskie, kamieńskie, płockie, wrocławskie, Teutonica, wlocławskie tylko 4, choć archidiakonat pomorski należal do diec. wlocławskiej. Nadto były mszały: antiqunm, incerti autoris vetustissimum, pergamenum scriptum ${ }^{6}$ ).

A genda. Na ogól miały już kościoły Agendę Powodowskiego, której pierwsza część wyszła w r. 1591, druga w 1592, drugie wyd. w 1596. Agendą dawną (Agenda antiqua) posługiwano się w Tarnawie $^{7}$ ), Lapanowie $^{8}$ ), Pogwizdowie ${ }^{9}$ ).

Antiphonarium. Przed r. 1596 nie notuje Estreicher w swej "Bibliografii" ani jednego drukowanego Antiphonarum. Sąsiadujące z sobą parafie: Biskupice i Łazany mają Antiphonarium pruthenicum, obie pergaminowe. Téz pergaminowe, ale bez podania jakie, ma Gdów ${ }^{12}$ ), papierowe nowe pisane ma Chełm ${ }^{13}$ ) i Sobolów ${ }^{14}$ ); Niegowić ma papierowe podarte ${ }^{15}$ ).

- $\left.{ }^{6}\right)$ Kujot, St., Visitationes archidiaconatus Pomeraniac. Torunii, 189?1899, str. 636.

7) A. V. $1596, \mathrm{k} 67$.

8) I. c. k. 65 .

،) l. c. k $184 \mathrm{v}$

10) l. c. k $216^{\mathrm{v}}$

11) l. c. k $214^{\mathrm{v}}$

12) l. c. k 213

13) l. c. $\mathrm{k} 18 \mathrm{v}^{\mathrm{v}}$

${ }^{14)}$ l. c. k 186

15) l. c. $\mathrm{k} 211^{\mathrm{v}}$ 
Graduale. Gradual mają prawie wszystkie kościoly. Łazany tylko mają drukowany ${ }^{16}$ ), Lapanów ma Pruthenicum ${ }^{17}$ ) Graduale. Gradualy poza tym są pergaminowe, papicrowe ma Łapczyna ${ }^{1 *}$ ) i Sobolów ${ }^{10}$ ), drukowany jest też papierowy.

P s a 1 te ri um. Psalterz ma co druga parafia w okolicy Niegowici. Bez Psałterza jest Sobolów, Pogwizdów, Tarnawa, Biskupice; pergaminowy posiada $\mathrm{Chełm}^{20}$ ), Gdów ${ }^{21}$ ), inne kościoły posługują się papierowym.

Komplet ksiąg liturgicznych dla kościoła stanowił mszał, agenda, antyfonarz, graduale, psałterz i agenda. Jutrznia i Nieszpory stanowiły, poza Mszą, nabożeństwo niedzielne.

W archidiakonacie pomorskim należy graduał, psałterz i antiphonarz do rzadkości - po kilka wypadków na caly archidiakonat. Agendy zaś są najróżnorodniejsze, ale agendę swej diecezji tzn. włoclawską ma tylko jeden kościół. Na ogół posługują się gnieźnieńską, wielu używa krakowskiej i Agendy Powodowskiego ${ }^{22}$ ).

\section{NACZYNIA LITURGICZNE.}

Ki el i chy. Mając zestawienie z 19 par, jakie one miały kielichy, widzi się pewną rozmaitość: są mosiężne, cynowe, srebrne i srebrne pozłacane. Mosiężne (aeneas) są w Myślenicach trzy ${ }^{23}$ ), w Jaworniku jeden ${ }^{24}$ ); cynowe po jednym w Lapanowie ${ }^{25}$ ), Jaworniku ${ }^{26}$ ), Pogwizdowie ${ }^{27}$ ), na Chełmie ${ }^{28}$ ) i w Gruszowie ${ }^{29}$ ) (Gïuszów ma tylko ten jeden cynowy), poza tym są srebrne, przeważnie pozłacane. Para-

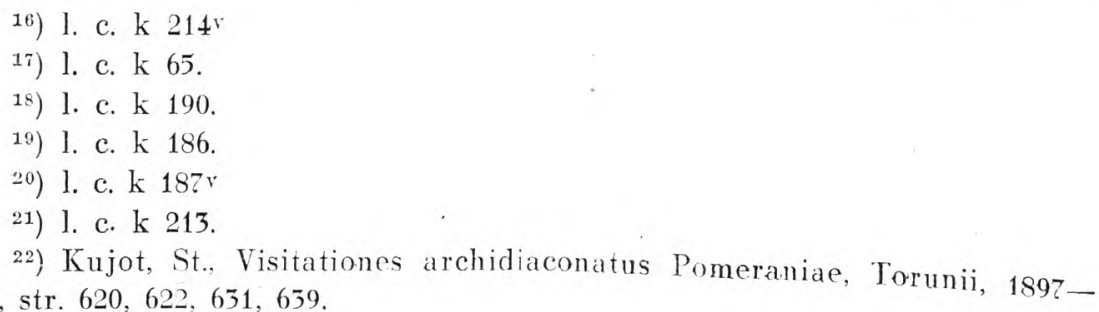
1899 , str. 620, 622, 631, 659

${ }^{23)}$ A. V. $1596 \mathrm{k} 38^{\mathrm{v}}$

${ }^{24)}$ l. c. $\mathrm{k} 42$

25) 1. c. k $64 \mathrm{v}$

26) l. c. k 42 .

$\left.{ }^{27}\right)$ l. c. $\mathrm{k} 184^{\mathrm{r}}$.

28) 1. c. $\mathrm{k} 187$.

29) 1. c. k 63. 
fie wiejskie mają po 2 (Biskupice $\left.{ }^{30}\right)$, Pcim $\left.{ }^{31}\right)$ ) lub po trzy (Droginia ${ }^{32}$ ), Niegowić ${ }^{93}$ ), Lapczyca ${ }^{34}$ ))), miasta znacznie więcej: Wieliczka $8^{35}$ ), Myślenice $7^{38}$ ), Bochnia $7^{37}$ ), Dobczyce $5^{38}$ ), tylko st. Wiśnicz ma $6^{39}$ ), ale Wiśnicz St. to troska Kmitów. Bochnia 4 wolne kielichy zastawila za $78 \mathrm{zl}$. (Obligaverunt) ${ }^{40}$ ).

Nie kwestionuje wizytator stanu kielichów, tylko zakazuje odprawiać w kielichu mosiężnym ${ }^{41}$ ).

Porównując ilość kielichów w Niegowici ź 1596 r. z ilością z 1748, widzi się, że liczba nie wzrosła, bo w 1748 r. były 4 kielichy.

O robocie kielichów nie ma wzmianki, tylko w Dziekanowicach jest mowa o srebrnym kielichu pozlacanym , in forma romana" ${ }^{42}$ ).

Monstrancje. Nie wszędzie mówi wizytator o monstrancji. Jeśli jest, to ją opisuje, czasem dość dokładnie. Rozmaitość była wielka. Byla miedziana (w Gruszowie ${ }^{43}$ ) i Pogwizdowie ${ }^{44}$ )), poza tymi są srebrne różnej wielkości (na Chełmie parva ${ }^{40}$ ), iusti ponderis" w Sobolowie $\left.{ }^{46}\right)$, Myślenicach $\left.{ }^{47}\right)$, i Wieliczce ${ }^{18}$ ), niektóre mialy podstawę cynową $\left(\right.$ Chełm $\left.{ }^{49}\right)$, Łapczyca $\left.{ }^{50}\right)$, Pcim $\left.{ }^{51}\right)$ ) nieraz byly pozłacane. Wymieniając, co było pozłacane w monstrancji, podaje mimo woli jej wygląd i tak w Pcimiu slońce, świat (globum), aniolowie

$\left.{ }^{30}\right)$ l. c. k 216.

31) l. c. $\mathrm{k} 36 \mathrm{v}$.

32) l. c. $\mathrm{k} 45 \mathrm{r}$.

33) l. c. k 210 r.

:34) 1. c. $\mathrm{k} 189 \mathrm{r}$.

35) l. c. k 219v.

36) 1. c. $\mathrm{k} 6$ ?

3i) l. c. k 191\%.

38) l. c. k 4-v

39) 1. c. k $20 \%$

40) l. c. $\mathrm{k} 191 \mathrm{r}$

$\left.{ }^{41}\right)$ l. c. $\mathrm{k} 42^{\mathrm{v}}$.

42) l. c. k 49v.

4:3) l. c. k 65 .

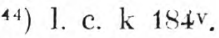

45) 1. c. $\mathrm{k} 18 ?$.

46) l. c. k $185 \mathrm{v}$.

47) 1. c. k $38^{4}$.

48) 1. c. k $219 \mathrm{v}$.

49) 1. c. k 187.

50) 1. c. k $189 \mathrm{v}$.

51) 1. c. k 57. 
i obraz Matki B. "a), w Drogini słonce i świat "az). Ozdobe monstrancji w postaci wianka $z$ pereł miały Myślenice ${ }^{54}$ ). Specjalny wygląd miała monstrancja w Łapczycy, bo między słońcem a podstawą miała srebrny krzyż, w którym umieszcza się N. Sakrament. Dosłownie: in qua Sacramentum reponitur ${ }^{55}$ ). Jeszcze bardziej odbiegał sposób stosowany w Niegowici, o ile chodzi o monstrancje. Tam srebrny krzyż służył jako pacyfikal i jako monstrancja przez nałożenie kwiatów na wierzchołek krzyża i na boczne jego ramiona. Był też wianek z pereł ozdobiony złotymi nićmi, który nakładano na monstrancję ${ }^{56}$ ).

Wkrótce po 1596 r. są znaczne zmiany na lepsze. Niegowić ma już monstrancję srebrną pozłacaną wagi 14 grzywien ${ }^{57}$ ), Gdów 18 grzywien ${ }^{58}$ ), Bochnia srebrną, wysoka prawie na dwa lokcie ${ }^{59}$. Prawie wszystkie to dary kolatorów, jak świadczą herby lub nawet napisy: w Niegowici herb Polkozic, więc Niewiarowski ${ }^{80}$ ), w Eazanach Sebastian Lubomirski, jak świadczy napis i herb ${ }^{01}$ ), w Niepołomicach Jan Branicki Łowczy krak. i starosta Niepolomski ${ }^{62}$ ). W Gdowie proboszcz i kolator Stefan. Weselin ${ }^{6:}$ )

C ib or i um. Znaczenie slowa ciborium nie zawsze i nie wszędzie było jednakie. Tu chodzi tylko o stan faktyczny, jak przechowywano Najśw. Sakrament w niektórych kościołach krakowskiej diecezji. Wizytator z 1596 r. ciborium nazywa miejsce, gdzie przechowuje się Najśw. Sakrament, więc podaje, że jest wykute w murze ${ }^{64}$ ), albo $\dot{z} e$ jest żelazne przymocowane do ściany ${ }^{65}$ ), albo że jest murowane przy

52) 1. e. $\mathrm{k} 5 \%$.

5.) 1. e. k $45^{\prime}$.

5) 1. c. $\mathrm{k} 30 \mathrm{r}$.

1.) l. c. $\mathrm{k} 189 \mathrm{r}$.

5ii) 1. c. $\mathrm{k} 210$...habet crucem argenteam cum pede aereo deargentato pro duplici usu: nempe et pacificalis et monstrantiae, superpositis certis floribus summitati crucis et lateribus... Item habet sertum cum margaritis, filis aureis exornatum pro monstrantia ponenda...

57) A. V. 1618 k $128 \mathrm{v}$.

58) 1. c. $\mathrm{k} 130$.

59) 1. c. k 29.

(iv) l. c. k 128 .

(i1) 1. c. k $124 \%$

(12) A. V. $1650 \mathrm{k} z^{\mathrm{v}}$.

(6i) A. V. $1618 \mathrm{k} 130$.

64) A. V. 1596 k 49

(55) 1. c. k 189. 
ścianie $\left.{ }^{66}\right)$. Poza tym, na 16 kościołów, nie podaje, gdzie jest ciboriun umieszczone, tylko materiał, z jakiego jest zrobione: muratum, egregie muratum, ligneum. Zwraca uwage, jaki jest jego stan. Chodzilo mu o to, czy jest czyste, bezpieczne, dobrze zamknięte. Na ogół wszystkie ciboria odpowiadały tym wymaganiom, jedno tylko bylo nie bardzo zabezpieczone, jedno niezamknięte.

We wnętrzu ciborium było albo naczynie (vas), abo skrzyneczka (scatula). Naczynie było metalowe, na ogół miedziane, w jednym wypadku cynowe, w jednym srebrne, w jednym drewniane. Nie ma powiedziane, jakiego kształtu, ale w vas mieści się ksztalt okrągly (walec). Skrzyneczka byla drewniana, wizytator nie oznacza, z jakiego była materiału, tylko że obita była (obducta) jakąś materią, albo że była malowana. Tam, gdzie w ciborium było vas, to było ono okryte welonem (coopertum). Wela przeważnie byly białe, trafiały się czerwone (rubei coloris), w jednym wypadku bylo żólte. Jak materiał, z którego bylo vas, różnej był jakości, tak też zaslona (velumı) na vas, i tak: jedwab prosty, jedwab małej wartości, camcha starożytna, adamaszek starożytny, bo „antiquus" to chyba nie stary, lecz starożytny; w Dobczycach zaś, gdzie vas było srebrne pozłacane, i veluin na vas bylo jedwabne, złotem przetykane (de serico auro intertexto) i ozdobione perłami. Vas było ze strusiego jaja, mając nakrywe srebrną, pozlacaną, tak samo nóżkę-podstawę ${ }^{67}$ ). W Łapczycy "na Górze“ bylo przymocowane do ciborium (stabile) ${ }^{68}$ ).

Najśw. Sakrament przechowywano we woreczku (in sacculo), tylko w Dobczycach wprost we vas, jak zaznacza wizytator (sine sacculo). Woreczek był albo we vas czy w scatula, albo w małym vas, które znajdowało się we vas. Najczesściej były dwa vascula parva, umieszczone w vas, w obu był Najśw. Sakrament. Jedno z nich służyło do niesienia komunii chorym. Vascula byly srebrne, miedziane, cynowe, drewniane; drugie było zazwyczaj drewniane. W Tarnawie noszono Najśw. Sakrament do chorych w skrzyneczce (scatula) ${ }^{69}$ ).

66) 1. c. $\mathrm{k} 212$ r.

$\left.{ }^{67}\right)$ 1. c. $\mathrm{k} 47$ Ciborium mutum, in vas, argcinteum deauratum podem habens et superiorem partem, ipsum vero de ovo struttionis, velo de serico, auro intexto, coopertum margaritis exornato, in quo Sacramentum recens sine sacculo continetur.

68) A. V. $1596 \mathrm{k} 189$.

69) l. c. $\mathrm{k} 66^{\mathrm{r}}$. 
W 1596 r. nic ma mowy o korporale pod Najsiw. Sakrantentem. Sledząc dalszy los ciborium tylko na przykładzie w Niegowici, to widzi się, że wizytatorowie posługują się stale terminem ciborium.

W 1618 r. okrcśla wizytator, że ciborium est in altari maiori in tabernaculo ${ }^{70}$ ): Wtedy też i w Gdowie nie znajdıje się już przy ścianie, lecz na wielkim oltarzu ${ }^{11}$ ). Już w 1618 r. vas cupreum zastępuje pixis argentea ${ }^{72}$ ) i 1665 jest pozłocona ${ }^{7 "}$ ), w 1703 r. zaznacza wizytator, że wewnatrz ${ }^{i 4}$ ). W 1629 r. znajdowały się komunikanty we woreczku, umieszczonym w puszce $\left.{ }^{75}\right)$. W $1703 \mathrm{r}$. bylo cale ciborium wewnątrz pozlocone, wtedy też byla na puszce sukicnka gustowna (vesticella eleganti contecta) ${ }^{76}$ ). Ze puszka stoi w ciborium na korporale, nadmienia dopiero wizytator w 1741 r. ${ }^{i}$ ). I naczyńko dla noszenia komunii chorym jest w $1629 \mathrm{r}$. ze srebra ${ }^{78}$ ).

Dekrety reformy, wydawane przez wizytatorów, wskazują linię, po jakiej szła władza duchowna co do ciborium. Jest ich mało, czyli że stan był na ogół zadowalający. Zabrania używać woreczka jedwabnego na przechowywanie Sanctissimum i nakazuje używać tylko Inianego, woreczek ma być poświęcony; Sanctissimum ma być w dwu naczyńkach, ażeby, gdy ksiądz idzie z jednym do chorego, było w kościele Sanctissimum dla adoracji. Kluczyk od ciborium miał być w zakrystii (sacrarium).

\section{MSZA SW.}

W żadnej parafii nie natrafił wizytator na jakieś braki co do materii Mszy św. Mogę mówić o jakich 30 parafiach. Wino miało należny sobie zapach i smak. Co do chleba to zabrania używać mąki zbieranej od ludzi do wypieku (de farina mendicata), nakazując piec co tydzień. a renovatio Sanctissimi robić co dwa tygodnie.

$\left.{ }^{70}\right)$ A. V. $1618 \mathrm{k} 128 \mathrm{v}$

71) 1. c. $\mathrm{k} 130$.

$\left.{ }^{72}\right)$ l. c. $\mathrm{k} 128 \mathrm{r}$.

73) A. V. $1665 \mathrm{k} 355$.

74) A. V. $1705 \mathrm{k} 99$.

75) A. V. 1629 k 9.

78) A. V. 1705 k 99.

77) A. V. 1741 k 1331.

78) A. V. 1629 k 9. 
Celebrowanie Mszy św. było rzadkie. Wyjątkowo był ksiądz, który odprawiał codziennie, na ogól odprawiali trzy razy w tygodniu: niedziela, środa, piątek, ale nie jest rzadkością, że tylko w niedzielę.

Nie wynika jasno $z$ wizytacji, gdy jest mowa, ze 3 razy w tygodniu jest Msza św., o ile jest przy kościele więcej niż jeden ksiądz, czy niezależnie od tego, ilu jest księży, jest Msza we środę i piątek, czy że każdy odprawia, oprócz niedzieli, także w środę i piątek.

Częstości celebrowania odpowiada rezydencja proboszczów. W 1596 r. na 18 parafii rezydowało 8 (44\%), nierezydowało $7(33 \%)$, nieobsadzonych było $3(16 \%)$, w 1618 r. na 16 parafii nie rezydowało 8 , w tym 4 to duchowieństwo katedralne (2 kanoników, 2 wikarych), 2 proboszczów nie miało święceń $(12 \%)$, rezydowało $6(37 \%)$. Są to lata dość bliskie soboru trydenckiego.

W sposobie celebrowania zastał wizytator w 1596 pewne nadzwyczajności: w jednym nie umial ksiądz odprawić Mszy św. wedlug rytı rzymskiego, w drugim odprawiał Missa sicca, czy jak ją określano w Aktach wizytacyjnych „Missạ Saxonica“. Chodziło o N. Targo i Waxmund. Ksiądz z N. Targu dojeżdżal ze Mszą św. do Waxinunda. Do Credo odprawiał jak należy. Po Credo miał kazanie, po kazaniu ludzie śpiewali pieśni eucharystyczne (aliquot cantilenas), potem ksiądz błogoslawil, intonując: Ecce panis angelorum ${ }^{\text {in). }}$.

\section{CHORZY.}

Z k o mu n i a do chorego szła procesja. Kościoly mialy choragwie z latarniami (vexilla cum laternis) jedną albo dwie pary. Wizytator tam, gdzie tego nie robiono, nakazywał, ażeby ksiądz, idąc do chorego, bral dwa komunikanty. W przeciwnym bowien razie klękaliby ludzie bezpodstawnie, gdy ksiądz wraca od chorego bez Sanctissimum, ale z chorągwiami. Chociaż świadkowie, badani przez wizytatora, czy ktos w parafii nie umarl bez zaopatrzenia, biora na uwage wiecej lat, na-

\footnotetext{
5) A. 1. $1596 \mathrm{k}$ 5- Rector scholar: rectorem ecclesiae (Novum lirrum N. Targ) feriis muncuam celebrare. In ecclesiis, quae sunt filiae huius ecclesiae. siceam Missam illum celebrare vel potius saxonicam, nempe ab Introitu usque ad Symbolum omnia integra, concione vero facta praemiscis cantionibus aliquot polonicis, ex ciborio Sacramentum allatum exhibet poprulo cantando: Ecce panis angelorum etc. Inni świadkowic nie potwierdzaja wszystkich zeznaú rektora szkoły; podaja, że try razy w tygodnin celebruje a missa sicca, podobno w Waxmundzie (k 58).
} 
wet do kilkunastuู, to jednak mogą wskazać wyjątkowo jakiś zgon bez zaopatrzenia. I właściwie nie twierdzą stanowczo, że ksiądz nie chcial, niejasno tylko wychodzi czasem sprawa, czy ksiądz był chory i nie czuł się na siłach do dalszej drogi, czy też zwlókł z powodu pogody, a śmierć mimo deszczu czy zawiei przyszła do chorego.

Inaczej wygląda sprawa $\mathrm{z}$ ostatnim namaszczeniem. Członek komitetu kościelnego (vitricus ecclesiae) pytany przez wizytatora, czy ksiądz udziela ostatniego namaszczenia, odrzekł, iż nie wie, co to jest ${ }^{80}$ ). Rector scholae $w$ Łapanowie podał wizytatorowi, iż za niego w ciągu 30 lat tylko dwa razy ndzielal ksiądz choremu ostatniego namaszczenia ${ }^{81}$ ). Tak mniej więcej było w całej okolicy. Jeszcze w 1630 wzywa wizytator poszczególnych proboszczów, ażeby nauczali lud w kazaniach o ostatnim namaszczeniu ${ }^{82}$ ). Sakrament „Ostatniego Namaszczenia“ był w powszechnym użyciu w Królówce ${ }^{83}$ ).

S p ow i edź. Do wyjątków należała osoba, która by nie odbyła spowiedzi wielkanocnej. O przystępowaniu do sakramentu Pokuty poza czasem wielkanocnym można dowiedzieć się przypadkowo, jeśli w metryce śmierci zanotowano, kiedy ostatnio byla do spowiedzi osoba, która umarla nagle i bez zaopatrzenia. W 1596 r. zastal wizytator spowiadanie gromadne - turmatim (Gruszów) ${ }^{84}$ ), (Góra św. Jana) ${ }^{85}$ ) i nakazuje spowiadanie pojedynczych osób (singulariter). Inną osobliwością jest rozgrzeszanie $z$ rezerwatów przez księdza w. Wilkowisku na tej podstawie, iż odbył swego czasu pielgrzymke do Rzymu. Otrzymal zakaz od wizytatora ${ }^{86}$ ).

\section{BIERZMOWANIE.}

Bierzmowaniem nie interesują się wizytatorzy. Nie ma mowy, czy bierzmowali, jeśli mieli Sakrę biskupią; jeśli nie mieli, to nie pytali,

$\left.{ }^{80}\right)$ A. V. 1618 k 101 Jan Kmicé vitricus w Rybiem: k 102 Jan Kulik karczmarz w Eososinie.

81).A. V. 1629 k 9 Brzezie, k 9v Niegowić.

83) A. V. $1618 \mathrm{k} 113^{\mathrm{r}}$.

84) A, V. 1596 k 64 Decreta reform... In domo plebanali et in sacrario confessiones non audiantur, sed in ecclesia tantum. Turmatim confessiones non audiantur, sed singulariter ssemper.

85) A. V. 1596 k 53 v Decr. reform. Domi confessiones non audiantur, nec in sacrario, ne nobilium quidem, nec turmatim.

86) A. V. $1596 \mathrm{k} \mathrm{61^{ \textrm {v } }}$ Decr. reform. In casibus reservatis et homicidiis neminem absolvere praesumat vigore peregrinationis Romanae. 
jak przedstawia się sprawa bierzmowania w poszczególnych parafiach i to od 1596 do 1748 r. więc roku, do którego są akta wizytacyjne, tyczące dek. wielickiego.

Libri ordinationum nie zawsze notowały udzielanie bierzmowania przez biskupa sufragana. Notują zaś nie tylko akty pontyfikalne sufragana, ale i innych biskupów, o ile np. udzielili święceń. Najskrupulatniej działo się to za Potkańskiego ${ }^{8 \pi}$ ), podobnie za Kaźmierza łubieńskiego ${ }^{88}$ ) i Michała Szembeka ${ }^{89}$ ).

Na końcu roku 1647 zanotowal Liber ordinationum, że sufragan Wojciech Lipnicki ${ }^{90}$ ) udzielił 1236 osobom sakramentu bierzmowania $\mathrm{w}$ ciągu tego roku w różnych miejscowościach ${ }^{91}$ ). Około tej rocznej obraca się ilość bierzmowanych w czasach, z których są dokładne zapisy, bo Szembek 1508, a Potkański 1415 osób rocznie. Chódzi tu o diecezję, która miała około tysiąca parafii. Jak wiele osób nie było bierzmowanych, widać to przy udziëlaniu tonzury. Potkański ma w swym Liber ordinationum, że po udzieleniu bierzmowania (praevia confirmatione i podana cyfra bierzmowanych), udzielił tonzury i święcen mniejszych. Nie można traktować wszystkich wtedy bierzmowanych za kandydatów do święceń, bo czasem wyraźnie zaznacza, że bierzmowal osoby obojga płci. Kilka jednak oryginalnych konsygnacyj kandyđatów do święceń, znajdujących się w Liber ordin, w których zaznaczono, kto bierzmowany, kto nie, daje podstawę pewną do sądu, jak wielka ilość kandydatów, przystępujących do święceń, nie była bierzmowana. I tak w 1767 r. na 8 kandydatów było 4 niebierzmowanych, w 1772 r. na 11 kandydatów 7 niebierzmowanych, na 5 było 4 bez bierzmowania, na 5 kandydatów bez bierzmowania 3 , na 4 kandydatów bez bierzmowania 2 . W sumie w 1772 r. na 25 kandydatów t11z przed tonsurą

8i) Acta Cameraria v. 34, p. 148v i n. Arch. Watykańskie. Franc. Potkański Kapł. diec. Gnieżnieńskiej został hiskupem Patarensis i sufraganem krak 23 lipca 1755, zm. 1789.

${ }^{88)}$ Acta Cameraria, v. 25, p. 90 Kazimierz Eubicński został biskupem Heraklei i sufrag. krak. 3 stycznia 1701.

8) Acta Cameraria, v. 25, p. 174. Michał Szembek, kapł. diec. krak. zostal biskupem Paphensis i sufrag. krak. 13 września 1206. Nastẹca jego byl Michal Kunicki od r. 1726.

90) Acta Cameraria, v. 19, p. 57v Wojciech Lipniecki został biskupem Laodicei i sufrag. krak. 2 lutego 1646. Nastçpa jego był Mikolaj Oborski od: $1658 \mathrm{r}$.

91) Liber ordin. nr 2. Arch. Konsyst. k 19. 
otrzymało bierzmowanie 16 czyli $60 \%$. Chodzi tu tylko o tych, których są konsygnacje oryginalne.

Dwa jubileusze 1701 i 1776 roku, kiedy polożyla nacisk władza kościelna na bierzmowanie, mówią, ilu ludzi było niebierzmowanych, bo w 1701 r. udzielono sakramentu bierzmowania 68.055 osobom ${ }^{92}$ ), a 1776 r. 112.155 osobom ${ }^{93}$ ). Chodzi tu tylko o bierzmowanie udzielone w Krakowie, w 1701 od 1 sierpnia do 30 listopada ${ }^{54}$ ), w 1776 r. od 23 kwietnia do 20 października ${ }^{95}$ ). Podziwiać trzeba ten naplyw do Krakowa ludzi z różnych stron, aby przyjąc sakrament bierzmowania.

Ze był wtedy napływ $z$ dalekich stron, świadczą cyfry bierzmowanych w Krakowie, pochodzace $z$ innych czasów. Za takie można uważać liczby bierzmowanych w kościele mariackim. Jest ich cztery: r. $1703,1704,1757,1759$. Trzy pierwsze to liczba bierzmowanych w tym kościele w Swięto Wniebowzięcia, a więc w dniu odpustu w kościele mariackim, czwarta w Nawiedzenie. W 1703 r. przystąpiło do bierzmowania 94 osób ${ }^{96}$ ), w 1704 r. $429{ }^{97}$ ), w 1757 r. 630 osób ${ }^{99}$ ), w 1759 r. 983 osób po poludni11 ${ }^{99}$ ).

Głównym kościołem Krakowa, w którym bierzmowano była katedra. Bierzmowano przed każdą tonzurą i minorkami, bo tonzury i minorek udzielono w tym samym dniu. Bierzmowanych jest wtedy nie wiele, są to kandydaci do tonzury, ale są i osoby inne. Liczba bierzmowanych w katedrze w czasie jednego i drugiego jubileuszu była ogromnie wielká.

Kościolem krakowskim, w którym często bierzmowano, byl kościól Nawiedzenia N. Marii P. na Piasku. Terminami było święto Nawiedzenia, częściej niedziela w czasie oktawy tego święta i uroczystość Matki B. Szkaplerznej. Od r. 1712 - 1724 odbylo sie tam bierzmowanie 9 razy,

92) Liber ordin. nr 4, rekopis niepagin. Archiv. Konsyst. Na rozpoczęce jubileuszu odbyl Kazimierz Łubieński jako admin. diec. sede vac. procesje z kościola mariackiego 1 sierpnia 1701 do katedry, gdzie odprawil Msse ponty fikalną. W procesji uczestniczyła kapituła, caly kler katedralny, wszystkie zitkony i Alma Universitas Carcoviensis. W sierpniu do bierzmowania 6943 osób, we wrześniu 24.548, w październiku 22.446, w listopad zie 14.318 osóh.

93) Lib. ordin. nr 9, k 108. Arch. Konsyst.

94) Lib. ordin. nr 4 rkps niepag. Arch. Konsyst.

95) Lib. ordin. nr 9, $\mathrm{k}$ 108, Arch. Konsyst.

${ }^{97}$ Lib. ordin. nr 4, rkps niepag. Arch. Konsyst.

97) Lib. ordin. nr 4, reps niepag. Arch. Konsyst.

48) Lib. ordin. $\operatorname{nr} 9, \mathrm{k} 23$. Arch. Konsyst.

49) Lib. ordin. $11 \mathrm{r} 9, \mathrm{k} 55 \mathrm{r}$. Arch. Konsyst. 
Potkański bierzmował tam jeden raz. Liczba bierzmowanych przekraczała 500, tylko w 1724 r., kiedy bierzmowanie było w samo święto Nawiedzenia, a w niedziele w oktawie bylo rano i po południu, to wtedy przystąpiło do bierzmowania 1628 osób ${ }^{100}$ ). Tak samo było w $1760 \mathrm{r}$. i wtedy liczba wynosiła 2135 osób $^{101}$ ).

Poza tym dość często było bierzmowanie u norbertanek na Zwierzyńcu w związku z ceremoniami zakonnymi, ale przystępowały i osoby świeckie. Jeszcze częściej w podobnych okolicznościach 11 wizytek.

Poza Krakowem było często bierzmowanie u benedyktynek w Staniątkach; gdy przybywal tam biskup dla coronatio virginum itp. Osób świeckich przystępuje wtedy do bierzmowania niewiele, po kilkanaście osób, tylko w r. 1758 na Sw. Wojciecha liczba bierzmowanych wynosiła $\left.227^{102}\right)$; w Staniątkach na św. Wojciecha jest odpust. W Mogile u cystersów bywało bierzmowanie na Znalezienie Krzyża (3/5). W $1761 \mathrm{r}$. przystąpiło do bierzmowania $693^{103}$ ) osób. W Jędrzejowie u Cystersów było bierzm. w 1765 i 1767 r. W 1765 r. udzielał Potkański bierzmowania przez Niedzielę, Poniedziałek i Wtorek Zielonych Swiątek. Wtedy liczba bierzmowanych wynosiła 2771 osób ${ }^{104}$ ), a w 1767 r. 754 osób ${ }^{105}$ ).

Są i inne kościoly zakonne, w których udzielano bierzmowania, ale ex re konsekracji kościoła czy ołtarza, np. u kapucynów w Rozwadowie w 1753 r. do bierzmowania 573 osób ${ }^{106}$ ), u bernardynów w Kalwarii w 1712 r. do bierzmowania 1555 osób ${ }^{107}$ ).

Bierzmowanie w kościołach parafialnych odbywało się wtedy, jeśli przybył tam biskup dla konsekracji ołtarza lub kościola. Biskup Su. fragan Potkański korzystal nadto z misji, by bierzmować ludzi i tak bylo w Przegini ${ }^{108}$ ) i Zwoleniu ${ }^{109}$ ). Na podstawie Liber ordinationum biskupa Potkańskiego, można podać liczbę parafii, w których było za niego bierzmowanie. Dotyczy to lat od 1753 do 1789, a więc 36 lat.

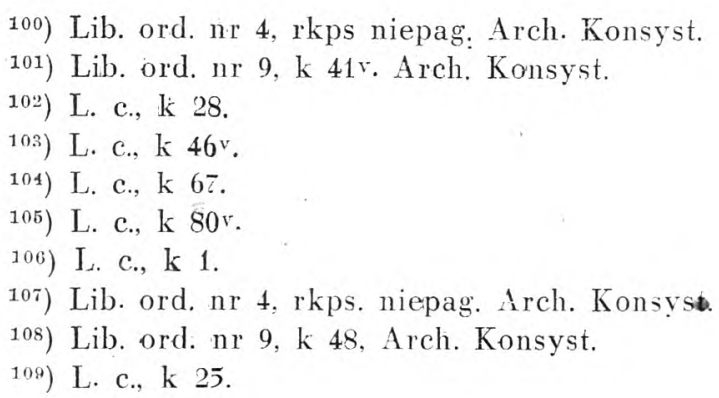


W tym czasie udzielił Potkański święceń kaplańskich 2653. diakonom, konsekrowal 24 kościołów, 99 stalych ołtarzy, poświęcił 686 dzwonów i udzielił bierzmowania 163.012 osobom, z tego w czasie jubileuszu . w samym Krakowie 112.155 osobom $^{110}$ ).

Biskup Potkański bierzmowal w ciągu swego życia w nastẹpujących parafiach poza krakowskich:

Biecz, 1766 r. 121 bierz. ${ }^{111}$ )

Bałtów 1753 (257) $\left.{ }^{112}\right), 1756$

$\left.\left.(241)^{113}\right), 1757(402)^{114}\right)$

Chlewisko 1777 (980) ${ }^{115}$ )

Droginia $1776 \quad(655)^{116}$ )

Dierzków 1757 (774) ${ }^{117}$ )

Gołcza 1759 (351) ${ }^{118}$ )

Inwałd $1756(987)^{119}$ )

Jędrzejów 1762 (105) ${ }^{120}$ )

Kosów 1766 (787) ${ }^{1: 1}$ )

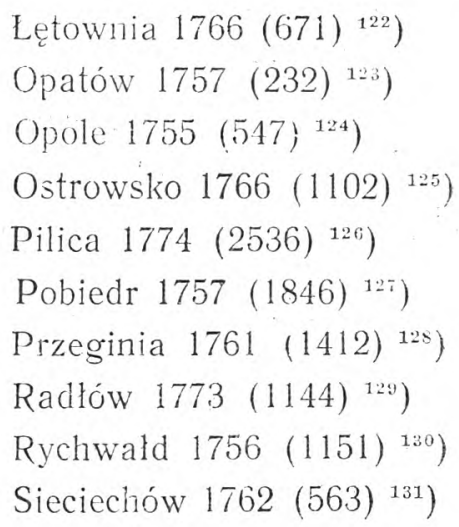

${ }^{110)}$ L. c., $\mathrm{k} 189$ ".

111) L. c., 735

$\left.{ }^{112}\right)$ L. c., $\mathrm{k} 1$.

$113)$ L. c., $\mathrm{k} 18 \mathrm{v}$.

114) L. c., k 28v Bałtów był par., którą St. Ap. pozwolila Potkańskiemu zatrzymaé, gdy prekonizowala go na biskupa-sufragana.

115) L. c., k 117 r.

116) L. c., $\mathrm{k} 111 \mathrm{v}$.

11i) L. c., k $24 \%$.

118) L. c.k $55 \mathrm{v}$.

$119)$ I. c., k. $17 \mathrm{r}$.

$120)$ L. c., k 55.

121) L. C., $\mathrm{k} 23^{\mathrm{v}}$.

122) L. c., k 75.

$123)$ L. c., k 25.

$\left.{ }^{124}\right)$ L. c., $\mathrm{k} 12 \mathrm{v}$.

$125)$ L. c., k 75.

12e) L. c., k 96.

12i) L. c., k $21 \mathrm{v}$.

128) L. c., k 48.

129) L. c., k 8 ?.

130) L. c., k 17.

131) L. c., k $53 \mathrm{v}$. 
Spytkowice 1766 (1646) $\left.{ }^{132}\right)$

Stopnica 1776 (1763) $\left.{ }^{13: 3}\right)$

Sucha $\left.1756(568)^{1: 4}\right)$

Slemień $\left.1756(53)^{135}\right)$

Trójca $\left.1754(142)^{1: 8}\right)$

Tyniec 1777 (167) 1.77)

Ujście Solne $1756(274)^{136}$ )
Ulina $\left.1759(243)^{139}\right)$

Wadowice 1756 (1039) $\left.{ }^{140}\right)$

Wierzchosławice $1772(858)^{1+1}$ )

Więclawice 1757 (380) $\left.{ }^{162}\right)$

Zakliczyn $\left.1776(653)^{143}\right)$

Zwoleń $\left.1755 \quad(405)^{14+1}\right), \quad 1756$

$\left.\left.(308)^{145}\right), 1757(460)^{146}\right)$.

W sumie było bierzmowanie w 32 parafiach, w których przystą. piło do sakramentu bierzmowania 26.242 osób.

W par. Niegowici najstarszą zapiskę, podającą liczbę bierzmowanych, jest w arch. paraf. zapiska z 1823 r., kıedy było 1149 osób do bierzmowania. Bierzmował biskup tarnowski Ziegler z okazji wizytacji kanonicznej. Parafia liczyla w 1820 r. 3553 dusz.

Bierzmowanie w niektórych punktach lączylo się na przestrzeni stuletniej z pewnymi wydarzeniami zewnętrznymi. I tak sufragan Kazimierz Lubieński z po'vodu najazdu szwedzkiego w 1705 r. święcii oleje w.Wielki Czwartek w Bochni, było to 9 kwietnia ${ }^{1+i}$ ), 21 maja 1705 r. udzicla święceń w Gorlicach, w Gorlicach też, poczynając 23 kwietnia, więc na św. Wojciecha, bierzmuje kilkakrotnie (264, 15,2/5 i na św. Trójcę), w Rożnowie bierzmował 19 7, 227, 267, po. tem jeszcze 4-krotnie (nie podane dni); tamze w Rożnowie udzielał

1:22) L. c. k 75 .

13:3) L. c., k 112.

1.4) L. C... k 17 v.

$135)$ L. c., k 171.

1:66) L. c., k ?.

137) L. c., k 117 .

138) L. c., $\mathrm{k} 18 \mathrm{r}$.

$\left.{ }^{1: 9}\right)$ L. c., k $35 \mathrm{v}$.

$\left.{ }^{140}\right)$ L. c., k 17 .

141) L. c., k S6r

142) L. c.. k $25 \mathrm{r}$

143) L. c., k 111r.

144) L. c., $\mathrm{k} 13$.

${ }^{1+5)}$ L. c., $\mathrm{k} 18^{\mathrm{r}}$.

146) L. c., k 25 Probosiwo " \%oleniu ratrzymal Potkański /a / goddạ St. Ap.. zostając sufraganem.

147) Liber. ord. nr 4. rkps niepay. Arch. Konsyst. Walse aht! K. Fubiénskiego " tym samym tomie niepag. 
Šwięceń $25 / 7,5 / 8, \sqrt{5} / 8$; we wrześniu i październiku udzielal święceń w Makowie.

Sufragan Michał Szembek, schroniwszy się na Sląsk przed zarazą w Polsce i rezydując w Tarnowskich Górach, udziela bierzmowania w różnych parafiach Sląska 6/1 1707 w Pszczynie, w Mikołowie 27/5, w Tychach 20/5, Bytomiu 7/6, Myslowicach we wrześniu, Tarnowskich Górach 23/2 1709. Swięceń udzielał przeważnie w Tarnowskich Górach, ale nadto w Mikolowie, Woźnikach, Książu ${ }^{148}$ ).

Sufragan Potkański schronil się w 1768 r. do Bielska austriackie. go z powodu zamieszek wojennych. We wrześniu $1772 \mathrm{r}$. powrócił i osiadł chwilowo w Radłowie, stąd wtedy bierzmowania jego w Radłowie i Wierzchosławicach ${ }^{149}$ ).

\section{PROCESJA Z NAJSW. SAKRAMENTEM NA DNI KRZYZOWE.}

Wizytator w $1596 \mathrm{r}$. wyraża się o procesji z N. Sakramentem na dni krzyżowe dosadnie i z tego już wynika, dlaczego ją zwalcza, mianowicie: vagari cum Sanctissimo per campos, circa fruges, czyli jest to dla niego ,włóczeniem się z Najśw. Sakr. po polach, wśród zbóż“. Zwyczaj ten istniał $w$ parafiach, które sąsiadowaly $z$ parafiami, nie praktykującymi tego zwyczaju. Jest on w Niepołomicach ${ }^{150}$ ), Lapczycy ${ }^{151}$ ), Bochni ${ }^{152}$ ), St. Wiśniczu ${ }^{153}$ ) i Pogwizdowic ${ }^{154}$ ), jest w $\mathrm{My}$ ślenicach ${ }^{155}$ ) i Gdowie ${ }^{156}$ ), nie ma go zaś w sąsiednich, więc nie ma w Biskupicach, Lazanach, Niegowici, Chelmie i Sobolowie, albo w Dobczycach i Drogini, które są między Myślenicami i Gdowem. Przy stwierdzeniu tego zwyczaju czy przy zakazie nie daje wizytator żadnych szczegółów, któreby pozwalały stworzyć sobic obraz choćby ogólnikowy, jak odbywała sie taka procesja. Nie można też twierdzic, czy nie było jej dawnicj w sąsiednich paraliach, tylko wyszły z użycia,

${ }^{148}$ ) Lib. ord. nr 4, rkps niepag. Arch. Konsyst. Wszystkie akty M. SzemJeka są w tym tomie. Par. W. Ksiąz zatrzymał M. Szembek za zgodą St. Ap., rostając biskupem sufrag. krak.

1+9) Lib. ord. nr 9, k 86r. Arch. Konsyst.

150) A. V. $1596 \mathrm{k} \mathrm{256 \textrm {r } .}$

151) L. c., k 190'.

152) L. c., k 19 r.

$153)$ L. c., k 208 .

15i) L. c., k $189 \%$

$155)$ L. c., $\mathrm{k} 41^{\prime}$.

1.56) 1. c.. k 215 , 
czy też nie było ich dawniej, jak nie było ich w 1596 r. A te, które miały ją w 1596 r., zachowały to, co miały od dawna. Jedno jest jasne, iż nie była to praktyka ogólna.

Zwyczaje religijne tkwiły głęboko korzeniami w sercu ludu; i zmiany w tym kierunku zachodziły powoli, nawet tam, gdzie pewne zwyczaje religijne były zwalczane przez kler. Moge jako przykład wskazać Hucisko Oleskie, wieś, należącą do parafii Podhorce archid. Iwowskiej. Wieś ta ma pewne zwyczaje religijne, których nie znają wsie sąsiednie, do tejże parafii Podhorce należące. Chodzi mi przede wszystkim o święcenie pól. Poza procesją na św. Marka i dni krzyżowe, urządzoną w kościele par. dla całej parafii, urządzają poszczególne wsi „święcenie pól“, tzn. idzie z kapłanem procesja z krzyżem, chorągwiami i feretronami wśród pól i kapłan święci pola. Takie ,święcenie pól" we wsi Hucisko Oleskie odbywa się inaczej, anizeli w innych wsiach par. Podhorce, mianowicie i tu przychodzi procesja z księdzem itd., ale zatrzymuje się przy czterech ołtarzach - stacjach, na ten dzień przygotowanych przy figurach przydrożnych, które już w tym celu stawiono w samym założeniu. Przy każdym ołtarzu śpiewa kapłan początek ewangelii, jak na Boże Ciało. Ma też ta wieś inny jeszcze zwyczaj, nie praktykowany przez wsie sąsiednie, mianowicie gdy przyjeżdża ksiądz do chorego, zbiẹrają się bardzo licznie przed domem chorego i czuwają z zapalonymi świecami. Gdy ksiądz nadjedzie, witają P. Jezusa śpiewem eucharystycznym, który nie ustaje do przyjęcia komunii przez chorego. Podobnie przychodza gromadnie, by modlić się przy zwlokach zmarłego i to bez przerwy, dzień i noc aż do wyprowadzenia do kościoła.

Chrześcijaństwo zastawało wszędzie obchody pól dla ublagania bóstwa o urodzaje i szczęśliwe zbiory. Weześnie też samo urządza podobne obchody błagalne dla uproszenia blogosławieństwa dla urodzajów u Boga Wšzechmocnego. Sposób urządzenia takiego obchodu, procesji błagalnej, święcenia pól rozwijal się z biegiem lat i w szczególach mial różne odmiany. $Z$ czasem wytworzyła się praktyka, że procesja zatrzymywała się przy 4 stacjach, przy których śpiewano początek czterech ewangelii, odmawiano wzggl. śpiewano odpowiednic modlitwy o urodzaje, o uchronienie od burz, gradu itp. udzielając błogosławieństwa przy każdej stacji.

Swięcenia pól z procesją teoforyczną nie było w XIII w. Pojawia się w XIV. W połowie XV w. zaczynają ją jedni pisarze zwalczać, ale 
u innych znajduje gorącą obronę, jako czegoś ogromnie drogiego dla kleru i ludu. Zakazy wladzy duchownej przyszły w XVI w.

Swieccenie pól, polączone z procesją teoforyczną było w Hiszpanii, Italii, Niemczech i Francji ${ }^{15}$ ). Praktyka wyrosła na wsi, niezależnie od katedry, które na ogół miały obrzędy mniej lub więcej zbliżone do rytuału rzymskego. W Niemczech przetrwały tu i ówdzie w formie zmienionej do XVIII w.

Wizytator, potępiając procesje teoforyczne, polączone ze święceniem pól, nie był wyjątkiem. Zajmując się tą praktyką, wskazał na zwyczaj, panujący u nas. Chodziłoby teraz o możliwie najdokładniejsze zestawienie parafii, w których odbywały się takie procesje i zależnie już od materiału wyciągać wnioski: czy tam, gdzie ich wizytator nie zastał, nigdy nie istniały, czy téz wcześniej wyszly z użycia, względnie łatwiej dały się usunać. Mnie się zdaje, że za tym faktem kryje się coś więcej, niż wcześniejsze zniknięcie tego zwyczaju, aniżeli gdzie indziej. Łamanie gałązek z drzewek, zdobiących oltarze na Boże Ciało i wtykanie ich potem w swym polu może świadczy o praktyce lamania gałąek przy ołtarzu w czasie procesji z 4 stacjami dla święcenia pól, bo wtedy następowało błogosławieństwo przy każdym ołtarzu, stąd też i drzewka przy oltarzu były blogosławione, a w takim razie zabierano ze sobą i umieszczano na swym polu coś pobłogosławionego i przez to przenoszono na swe pole blogosławieństwo pól, udzielane przy 4 stacjach w czasie święcenia pól.

\section{PROCESJA KOEO CHRZCIELNICY.}

Wizytator w 1596 zakazywal procesji czy obchodu - circuitus kolo chrzcielnicy, jaki odbywano w drugi dzień Wielkanocy i w drugi dzień Zielonych Swiątek. Obchód chrzcielnicy w te dni związany jest z udzielaniem chrztu na Wielkanoc i na Zielone Swięta, więc zdawało by się, że obchód, jako rodzaj przypomnienia sobie chrztu, i sposobność do podziękowania za przyjęcie na łono Kościoła przez polanie wodą zasługiwał raczej na zalecenie, niż na wytepienie. Zastał wizytator

157) Frantz, Adolph, Die kirchlichen Benedictionen im Mittelalter, II, str. 105. - Bliższe szczególy o procesjach teoforycznych dla święcenia pól na terenie Niemiec podaje powyższa praca, nadto na terenie diec. augsburgskiej. Ho ey n k, F. A. w dzicle Geschichte der Christlichen Liturgie des Bistums Augsburg, a diec. Bamberg Ha im er l Xaver " studium Das Prozessionswesen des Bistums Bamberg im Mittelalter. 
ten zwyczaj na pogórzu, bo w Jaworniku ${ }^{158}$ ), Myślenicach ${ }^{159}$ ), Tarnawie ${ }^{160}$ ), Wilkowisku ${ }^{161}$ ) i Łętowni ${ }^{162}$ ). Nie ma go ku północy od My. ślenic czy Tarnawy.

Zestawienie wszystkich miejscowości, w których ten zwyczaj żyl w 1596 r., dałoby podstawę do wniosków. Procesje naokoło chrzcielnicy odbywano w średniowieczu w W. Sobotę i w wigilię Zielonych Swiątek w związku ze święceniem wody chrzcielnej. Obchodzono chrzcielnice 7 razy, względnie 5 lub 9 razy ${ }^{163}$ ).

Mszał krakowski z 1532 r. ma rubrykę o̊ siedmiokrotnej procesji naokoło chrzcielnicy w W. Sobotę przy święceniu wody w czasie śpiewania litanii ${ }^{164}$ ). W wigilię Ziel. Swiąt bylo tak samo. Mszał krakowski z 1484 r. nie ma rubryki o takiej procesji na około chrzcielnicy.

\section{OETARZE.}

Wezwania poszczególnych ołtarzy są czymś dawnym, uświęconym i o zmianie ongiś trudno było mówić. Tym tlumaczyć trzeba brak kościoła w calej okolicy pod wezwaniem św. Stanisława biskupa. Gdy chciano mieć oltarz pod wezwaniem św. Stanisława, budowano kaplicę, w niej ołtarz główny św. Stanisława np. w Łazanach. W XVII w., zwłaszcza w XVIII w. panuje tendencja posiadania jak największej lczby ołtarzy, szczególnie wypełnione są nimi kaplice. Oltarze te są bardzo prowizoryczne i niejednokrotnie zasługują z trudem na nazwę ołtarza. Gdy kult niektórych świętych maleje, to nawet do głównego

150) I. V. $1596 k+21$.

15:) I. c.. $\mathrm{k} 41$ '.

1;0) L.. c.. k 6:'.

161) L. c. k 61:

162) L. c.. k 30 .

${ }^{163)}$ Ho e y n ck, F. A. Ceschichte der Christl. Liturgie des Bistmms Augsburg, s. 218. W sobotę obchodzono 7 razy, w wig. Ziel. Sw. 9 razy; Ha imel Xaver. Das Prozessionsvesen des Bistums Bamberg, s. 150 podaje, iz celebrans z duchowieństwem obchodzil chrzcielnice 5 razy przez 3 dni wielkanocne, z razy przez 5 dni Zielonych Świątek.

164) Missale sec. rit... eccl. cathedr. Cracoviensis, Venetiis. 1552, k. 96 Expletis autem lectionibus et canticis presbyter cum suis ministris procedunt ad faciendum fontem rexillis, cereo magno, thuribulo et scholaribus cum luminibus procedentibus, circumeundo infra litaniam eundem septem vicibus et chrysma inter crucem et evangelium portantes et lituniam pronunciantes. choro stando prope fontem in suo ordine. 
oltarza przychodzi obraz nowego świętego, cieszącego się duzym kultem, na miejsce dawnego.

O ile chodzi o obrazy Matki Boskiej, cieszące się wzrastającą czcią w Polsce i o patronów Polski, to ołtarz Matki B. Częstochowskiej by w XVIII w. w Wieliczce ${ }^{165}$ ), Biskupicach ${ }^{160}$ ), Eazanach ${ }^{107}$ ), Dobczycach ${ }^{168}$ ), Niepołomicach $\left.{ }^{169}\right)$, Lapczycy $\left.{ }^{170}\right)$, Pogwizdowie $\left.{ }^{171}\right)$, Tymbarku ${ }^{-172}$ ) i Wojniczu ${ }^{173}$ ); Matki B. na Piasku (Kraków), w Wieliczce ${ }^{174}$ ), tu też i Matki B. w Studziannie w Sandomierskiem ${ }^{175}$ ). Ołtarz św. Stanisława biskupa byl w Wieliczce ${ }^{17 i}$ ), Lazanach $^{177}$ ), Dobczycach ${ }^{118}$ ), Bochni $\left.{ }^{17 !}\right)$, św. Jana Kantego w Wieliczce $\left.{ }^{150}\right)$, Dziekanowicach ${ }^{881}$ ), Wiśniczu ${ }^{182}$ ), bl. Kingi w Wieliczce ${ }^{183}$ ), Bochni ${ }^{184}$ ); św. Kazimierza w Lapczycy ${ }^{155}$ ) i Wiśniczu $\left.{ }^{186}\right)$; św. Stanisława Kostki w Biskupicach ${ }^{187}$ ), św. Wojcecha byl tylko w St. Wiśnticzu $\left.{ }^{188}\right)$.

Tytuły kościolów, ołtarzy mają daleko bogatszạ wymowę niz to powyżej poruszono. Zeby śledzić rozwój kultu i szukać jego ojczyzny, to nie można poprzestać na samych aktach wizytacyjnych, choć XVI w. podaje to, co zastał po średniowieczu, a XVII i XVIII w. "wprowadzają

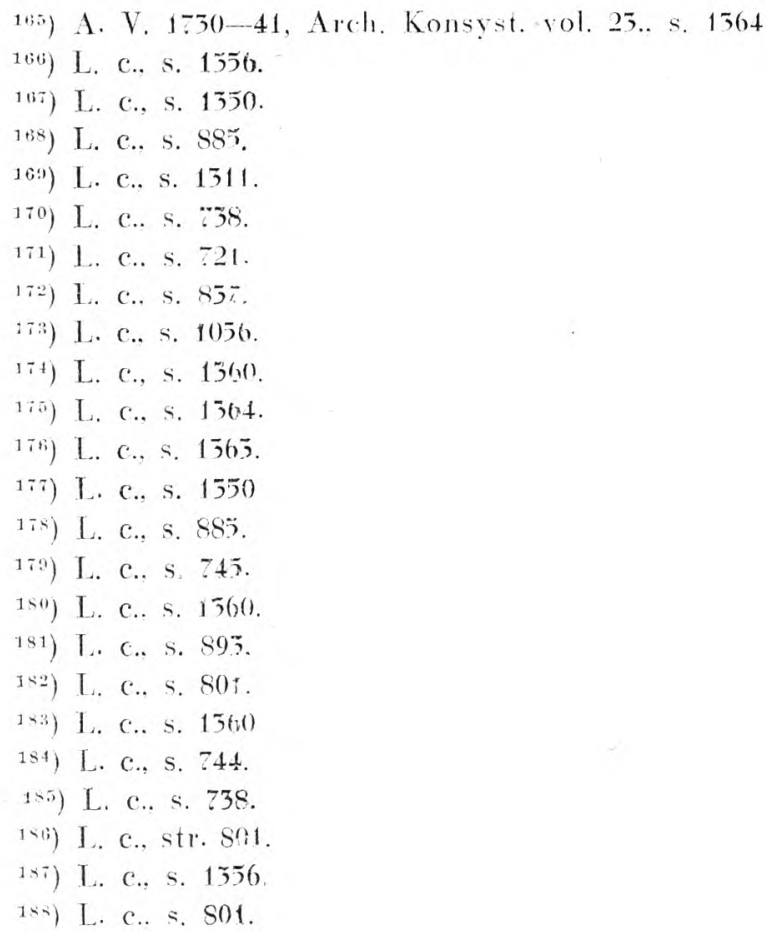


pewną płynność, która i obecnie trwa, co do wprowadzenia nowych nabożeństw i nowych šwiętych.

\section{UPOSAZENIE LITURGICZNE.}

Wszystko, czy naczynia liturgiczne, czy bielizna kielichowa, czy ornaty, jest w 1596 r. w niewielkiej ilości i ubogie. Nie jest rzadkością kielich cyńowy, puszka miedziana, parę puryfikaterzy, niewiele ornatów. To stan z końca XVI w. Liczba ornatów waha się wtedy od 26 (Wieliczka) do dwu (Gruszów, Tarnawa); tylko trzy ma Sobolów i Pogwizdów; Łapanów ma 4; Niegowić niala 15 ornatów. Ich liczba odpowiada zamożności uposażenia, czy weźmie się pod uwage świętopietrze w XIV ${ }^{189}$ ) i XVI w. ${ }^{190}$ ), czy podatek płacony przez duchowieństwo w 1634 r. ${ }^{101}$ ). Wieliczka płaciła w XVI w. 2 grzywien 6 skojców, Niegowić od 1 grzywny, Pogwizdów i Sobolów od 5 skojców i Wieliczka ma w XVI w. 26 ornatów, Niegowić 15, Pogwizdów 3, Sobolów 3, a 5 skojców to $1 / 92$ grzywien, jak 3 ornaty to $1 / 926$ ornatów, jak w 1634 podatek Sobolowa 3 zł. 18 gr. jest 1/9 podatku płaconego przez Wieliczkę, bo 29 zł. $18 \mathrm{gr}$. Nie wszedzic trzyma się ten stosunek bez. zmiany, bo Niegowić płaciła w 1634 r. 23 zł., a Pogwizdów 1 zł. Mała liczba puryfikaterzy i w ogóle bielizny kielichowej tłumaczy się rzadkością odprawiania mszy św.; dlatego Niegowić miala 15 ornatów i dwa puryfikaterze, Wieliczka na 26 ornatów 3 puryfikaterze, a niejedna parafia miała tylko jeden. Analogicznie było w życiu codziennym społeczeństwa, kiedy nawet przy wystawności stroju zewnętrznego zadawalano się minimalną ilością bielizny itp. ržeczy.

W 1748 r. wyposażenie zakrystii jest zupełnie inne. Dla przykladu biore tylko Niegowić. Wizytacja z 1748 r. zapisuje szczegółowo stan srebra w kościele, cyny, mosiądzu i miedzi, jakoteż szat liturgicznych, bielizny kościelnej, i całego wyposażenia kościoła w rzeczy potrzebne do procesji itd. ${ }^{192}$ ).

Ze srebra było:

4 kielichy pozłacane, 1 monstrancja pozłacana, ,staroświecką robotac w kolumny"; korona srebrna na obrazie Matki Boskiej, trzy małe

189) Ptaśnik, J., Monumenta Poloniae Vaticana T. I. passim.

190) Gromnicki, Tadeusz, X., Świętopietrze w Polsce, s. 510.

191) Contributionis sextuplae dioec. Cracoviensis.. 1634, Arch. kapit. krak. 8a. Rkps niepag.

192) A. V. 1748. Arch. Konsyst. v 40, s. 158-166. 
korony pozlacane na obrazie św. Anny, jedna korona pozlacana na obrazie M. Boskej noszonym; sukienka ,złotem robiona" na wielkim obrazie Matki B. w kaplicy, sukienka srebrna „złotem przerabiana“ na obrazie św. Anny, sukienka srebrna „złotem robiona“ na noszonych obrazach Matki B. Różańcowej i św. Józefa; 2 krzyże srebrne, jeden z zloconymi postaciami czteerch ewangelistów, drugi z jednej strony ze złoconymi aniołkami, z przeciwnej ze zloconymi postaciami czterech ewangelistów, pasyjka na drewnianym krzyżu na wielkim ołtarzu, dwa lichtarze, para ampułek $z$ tacą. W kaplicy 7 wotów srebrnych, korali na obrazach 37 nici, z tego 21 na obrazie św. Anny.

Pokaźna jest liczba ornatów, przy żadnym nie zaznacza wizyta tor, że jest nadniszczony, w każdym kolorze jest nowy ornat. Białych było 10 , czerwonych 8 , zielonych 6 , ,fiolkowych" 4, czarnych 4. Zrobione $z$ materii wartościowej, więc jest lamowy, parterowy, atłasowy, aksamitny, adamaszkowy, gryzetowy, z materii tureckiej wzorzysty, muchajerowy. Niektóre były w kwiaty srebrne i złote.

Dalmatyk 2 pary, kapy w każdym kolorze, antypedia też w każdym kolorze i to w bialym 7 , czerwonym 4, zielonym 3, ,fiolkowym" 2 , czarnym 1 z materii jak ornaty. Sukienka na puszke jedna była z jedwabiu „w karpiową luske“.

Nadto była odpowiednia ilość velum i burs.

Bielizna kościelna nie tylko jest liczbą pokaźna (12 alb), ale wyróżnia się ozdobnością, są np. 3 korporały szyte złotem i srebrenı, 16 z białym szyciem i koronkami, 2 z czarnym szycien. Puryfikaterzy. było 30. Trudno przepisywać cały inwentarz kościelny. Wspomnieć trzeba jeszcze posiadanie obić szkotowych, półjedwabnych, madzelonowych na bretów 10, 12, a nawet 21, 24 .

Inwentarz kościoła z 1748 r. pozwala stwierdzić ogronnną różnice między rokiem 1596 a 1748. Ileż w 1748 r. było srebra, jedwabiu, adamaszku itd. Nie 2 puryfikaterze jak w 1596, ale 30 posiada kościól w Niegowici.

Srebro i metale szlachetne zabrała Austria. Kościołowi została tylko srebrna kupa kielichowa, gdzieś w zakamarkach porzucona. Do niej dał dorobić podstawę, ażeby miał kielich. Kupił też nową monstrancję. Wydatki na kielich i monstrancje pokrył ze składek para$\left.\operatorname{fian}^{193}\right)$.

193) Liber iurium s. 164. Rkps w Arch. par. w Niegowici. Po zabraniu wszelkich naczyń srebrnych kościelnych na Skarb sprawila się monstrancja 
Jak w kościele niégowickim przybyło srebra i jedwabiu, adamaszku, atłasu, tak samo albo jeszcze bardziej zwiększyła się ilość srebra, atłasu itd. w domach szlacheckich, nie mówiąc o magnatach. Odwrotny zaś byl stosunek od XVI w. do XVIII, o ile chodzi o siłę obronną państwa. Ta z biegieni lat malała $i$ w drugiej polowie XVIII w. była w stanie opłakanym. Nie było czym bronić nagromadzonych skarbów, bo od dawna nie brano w rachube, że obronność państwa musi być na pierwszym planie.

Kraków

RS. TEOFIL DEUGOSZ

\section{NOWE: KSIĄŻKI}

\section{KS. EUGENIUSZ DABROWSKI: SWIETY PAWEE - ŻYCIE I PISMA Pallottinum. Poznań 1950. s. 329}

Ks. Eugeniusz Dąbrowski wydal w r. 194? w Warsawie nnane inteligencji katolickiej w Polsce dzieło pt.: „Drieje Pawla z Tarsu“. Naukowa wartość powyższej pracy i jej znaczenie dla biblistyki polskiej mialem sposobność ocenić na lamach „A teneum Kapłańskiego“ w tomie 47 z r. 1947, s. 478483. Recenzję moją zakończylem następujạcymi słowy. „Dzieło ks. D. nadaje się do czytania przede wszystkim dla duchowieństwa, studentów teologii i wykształconych katolików, ale będzie mało dustępne dla ogólu naszych wiernych, którzy nie mniej od księży, choć w innym ujęciu powinni znać życie i dzialalność św. Pawla. Dlatego w imieniu tych ostatnich zwracam się do Czcigodnego Autora z serdeczną prośbą, by poszedl w ślady Holznera i dal spoleczeństwu polskiemu zyciorys Pawła z Tarsu w wydaniu popularnym z pominięciem aparatu naukowego i opuszczeniem zagadnić́ interesujących jedynie zawodowych teologów. Do takiego dzieła o charakterze popularnym mógłby Autor włożyć więcej ciepła i serca niż to mógł uczynić w dziele czysto naukowym. Za taką pracę, której napisanie nie sprawi Autorowi większych trudności będzie mu zapewne społeczeństwo katolickie bardzo wdzięczne".

Ks. Dr D. uznał widocznie tak moje jak i wielu innych osób życzenie za słuszne, bo w trzy lata póżniej oglosil drukiem dla szerszych sfer społe-

ze składki parafian, uczynionej, za którạ wziạł Holcer 1500. Do zostawionej kościołowi jednego kielicha kupy srebrnej i pateny kazało się dorobić spodek ze składki parafian kosztem 160". Zapiska ks. Ludwika Kozickiego, prob. w Niegowici od r. 1803-1829. X. Kozicki sprawił tez dla kościoła kielich, wewnątrz i zewnątrz pozłacany, z pateną, za który zaplacił Holcerowi z własnych pieniędzy 400 zł. Patenę zảmykaną do chorych za 120 zł., ,krzyż do kościoła posrebrzany ze składki i z dołożeniem się“ ks. Kozickiego za 460 ८ł. 